これらはすべて大きくてもポケットに収まる程度に し，市民用のものは腕時計あるいはペンダントの大きさ の超小型としたので，利用性は著るしく拡大された。

\section{3. オゾン吸入による放射線防御}

砂田 教, 服部恵子, 加藤智雄 (大阪府立放射線中央研衛生工学)

従来厗告されてきた放射防御剂恃，被曝の直前あるい は被曝中に使用寸るか，または中毒量を投与しないと， その効果が期待でき奴ものが多い。そのため，たと党ば 放射線治療の如く，事前に被曝が-予期される場合を除い ては，実用価値は注とんどない。理想的な放射線防御剂 は，伝染病に対するワクチンの如く，放射線に対し，長 期の和性を獲得させるよらなものでなければならぬ。

Cronkite は, 低線量の放射線に, あらかじめ被曝した マウスが，後に大線量の放射線に対する酎性を猚得した ことを報告している。この方法は，放射線の遺伝に及ぼ す効果を考慮すれば避けたい。他方, Stokinger は, 低濃度の $\mathrm{O}_{3}$ を吸入したマウスやラットが致死濃度の $\mathrm{O}_{3}$ に対する酎性を獲得することを報告している。そこで， 我々は， $\mathrm{O}_{3}$ が1種の radiomimetic substance であ ることに注目し，低濃度（外見上なんらの傷害が認めら

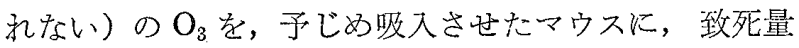
の放射線を被曝させてみたところ，著るしい放射線耐性 を獲得していることを発見した。耐性の持続期間が最大 限どれくらいか，及びすべての動物について事害である かが，今後の観察すべき事実であり，耐性出現の機構 を, Stokinger のいわゆるcross-tolerance や stress 説との関連に和いて考察することが，今後の問題とな らう。いずれにせよ, 放射線の防禦に関する新らしい笑 破口ぶ開かれ，今後の飛躍をこの実跧結果は約束するだ ろう。

\section{4. 街生材料の放射線殺菌}

砂田 毅，木下商策、加藤智雄 (大阪府立放射線中央研衛生工学)

放射線による殺菌法の利点は，あらかじめ使用量単位 ごとに包装された材料を，そのままで殺菌できることで ある。従って現場で処理できない野外, 戦場, 辺境の地 とか, 緊急事態の如き, 時間の余裕のない場合の救難の 準備に適する。殺菌のための材料の適性損失の程度を観 察して捈く必要がある。

衛生材料の贷表として, 脱脂綿, 紙綿, ガーゼ, 紏創 高，縫合系を取上げ，これらの市販包装品内容物に附着
していた菌を分離し，これに加らるに，E. coli，Staphyl. aureus, B. subtilis, Mycobact. tuberc., Clostrid. histol., を强制的にこれら材料に附着させた 場合の殺菌線量を求めた。分離された菌は Bacillus Mold であった。刹菌のためには，C $\mathrm{Co}^{60} の \gamma$ 線を線源 とした場合は， $2 \times 10^{6} \mathrm{rad} か ゙$ 最小必要線量であった。 つぎにこの線量及び $1 \times 10^{7} \mathrm{rad}$ の線量を与えられた各 材料の材料試験を行なった。即ち脱脂綿については圧縮 弾性, 吸水力, 溶性物, 紙綿については耐摩耗性, 吸水 カ, ガーゼについては强伸度, 吸水力, 溶性物, 絆創膏 については接着力, 切断強力, 縫合会については強伸 度，溶性物試眏を行ない，ぬた，それぞれの材料の実際 使用に括ける皮膚粘膜接触試験を行なった。いずれる $2 \times 10^{6} \mathrm{rad}$ をでの照射では，䚾とんどその特性を失な わ机なかったが, $1 \times 10^{7} \mathrm{rad}$ 照射となると, 著るしく変 性することがわかった（我及はこれを醣の線量と呼ぶ）。 経済的に放射線殺菌法沁ひさあうかといら問題が残る が，これは線源の供給量（将来は核然料要素の廃裹物が 利用できよう), 材料の処理量, 照射設備機棈（将来は 照射サービスせンター設置が考えられる）によって変動 主当。

\section{5. ${ }^{137} \mathbf{C}_{s}$ 内部照射が雄生殖器に与える影筤について の実験的研究（第 2報） \\ ${ }^{137} \mathbf{C}_{s}$ 内部照射を受けた雄の輁丸組織变化の 経時的追求と, ${ }^{137} \mathbf{C}_{s}$ の体内分布について}

\section{大平昌彦，田村年行（岡比大衛生）}

演者らは，さきに第30回日本衛生学会総会に和いて, ${ }^{187} \mathrm{C}_{s}$ 内部照射 が雄生殖器 の生殖能力に与える影響につ いて実験結果を発表し， $4 \mu \mathrm{c} / \mathrm{g}$ 投与組， $8 \mu \mathrm{c} / \mathrm{g}$ 投与組 ともに，妊娠率，胎仔数が投与後, 漸次低下し, 50〜60日 群において最低值を示したことを報告した。我及はこ 机ら妊娠率及び胎仔数の経時的变化々睪丸内 ${ }^{137} \mathrm{Cs}$ 分布 ならびにその組織学的変化との関連性を知るために, 今 回の実験を行なった。

実験動物は第 1 報に同じく, dd系ハツカネズミ生後 100 日前後, 体重·25gくらいのものを使用, 実験方法は雄 120 匹を 2 組に分け，工組は体重 $1 \mathrm{~g}$ 当り $4 \mu \mathrm{c}$ ，正組には同じ $<8 \mu \mathrm{c}$ を腹腔内投与，投与後12時間，24時間， 2 日， 3 日，10日，20日，30日，以後10日目ごとに，100日後 まで，I，四組とも 5 匹ずつを頸動脈切断放血により虚 殺, 骂丸考取出し, 型の如く組織標本を作成, 細精管内 精子形成の ${ }^{137} \mathrm{Cs}$ 内部照射による影響を検討した。その 結果, 啐丸内精子形成諸細胞は， ${ }^{137} \mathrm{Cs}$ 投与㣪，次第に 
減少，変性，消失が和こるが，それ杜前報，妊娠率及び 将数の経過ときわめてよく対応することを知っだ。

また同時江睪丸, 腎, 脾, 肝, 心, 肺の各臟器を摘出 し， ${ }^{137} \mathrm{Cs}$ 体内分布状態をも垖求した。ウェル型シンチレ ーションカウンターによって測定した結果, $1 \mathrm{~g}$ 臟器当 りのcpmは投与後 $2 \sim 3$ 日に最高で, 以後, 濑次低下, 枵器器の比較は投与後 20 日目以後は睪丸がつね水最高值 を示しついで心臓，肝臓が多かった。

\section{6. 電気透析法による血中 $\mathrm{Sr}^{89}$ の除去について}

鏡 光長

(慈大公衛)

井上武一郎，山田憘政，秋山 俊，行田镦夫 (武蔵工大原研)

吾ふは，さきに体外循環経路に打いて，電気透析法に よるUranium の除去について報告してきたが，今回 法上述の装置を用いて， $\mathrm{Sr}^{89}$ につき実験検討をし，興昧 ある三，三の知見を得たので報告する。

実験方法

1) in vitro : Ringer液, 灌流液, 保存血等火一定量 の $\mathrm{Sr}^{89}$ を spike 乙, 最大上昇限界を温度 $40^{\circ} \mathrm{C}$, 電流 $6000 \mathrm{~mA}$, 電压 $20 \mathrm{~V}$ の藷条件の下に, 透析効果を試及た。

2） in vivo：実験動物は大を用い， Ringer 液に既 知の $\mathrm{Sr}^{89}$ spike したものを，あらかじめ静注し，股 動静脈を用いてラボナール麻酔下に，体外循環経路に導 き，前記諸条件の下に透析効果を娭討した。

結果： 1 回 2 時間の電気透析により，約50\%を上孪わ る除去効率を見た。

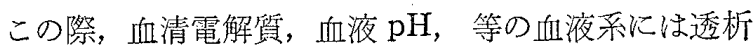
前後を通じて，注ぼ正常範围にとどるることを知った。

\section{7. 電気透析法による血中 $\mathbf{C s}^{137}$ の除去効果 について} 井上武一郎，山田㥶政，秋山 俊，行田敏夫， 片岡兄一－(武蔵工大原研） 鏡 光長 (慈大公衛)

Fission products $の$ first aid の重要性に鑑み, 吾 々はその生体内除去に関する一連の研究を報告してきた が，今回は血中 $\mathrm{CS}^{137}$ の電気透析法に上る除去効率につ いて，in vitro 及び in vivo の実験を行なったので報 告する。

即ち in vitro では, Ringer, 灌流液, 保存血にあら かじめ既知量の $\mathrm{Cs}^{137}$ を spike 乙, 温度, 電流, 電圧, 除去効率等についてしらべ, in vivo では，あらかじめ $\mathrm{Cs}^{137}$ で spike した Ringer 液を犬に静注し, 温度, 電流，電生，除去効率を 2 時間纫わたり観察した。
以上の実験から， $\mathrm{Cs}^{137}$ の電気透析法に上る除去効率 は, 前記条件の下においては, 最高 (in vitro) 80\%で あり， $\mathrm{Sr}^{89}$ に比較し約1.5〜2 倍の効率を示した。

$\mathrm{Cs}^{137} ; \mathrm{Sr}^{89}$ 除去効果の差異坆して，種々の考察を 加えた。

\section{8. $\operatorname{Sr}^{90}$ と $\mathrm{Cs}^{737}$ のマウスの成長と生殖に及ぼす影響}

西尾一男，杉浦咲子（大阪府立放射線中央研）

核実験汇よって, 現在もなお，放射性降下物が降下乙 つつあるが，現在までのところで注，新生物，白血病な どの疾患が，将来增加主る危険性性，生物統計学的見地 からは推定されるが，実験による核分裂生成物（FP） に, 明らかに帰因しらるような可視的障害（胎児発育障 害，造血機能障害など）を人間にひきおこ方潘ぞのもの ではない。これ詨して，核戦争がう一和これば，爆弾 からの熱線之放射線炕よる直達的損鹪の活か炕，爆発後 飞, 強烈な放射性降下物が，我々の環境を污染して，食 物や水を介して，長期にわたってFP方，人体内に大量 に侵入してくることが問題である。

このような見地から，FPのうちで最も害作用の強い $\mathrm{Sr}^{90}$ と $\mathrm{Cs}^{137}$ を混じな水で，純系マウスNA2 を飼育し て，その成長と生殖に及济す影響を追究した。

新生マウスに，離乳後， $\mathrm{Sr}^{90}$ と $\mathrm{Cs}^{137}$ をそれぞれ0.1 及び $0.4 \mu \mathrm{c}$ を混じた水で飼育した群をI，その $1 / 10$ 及び $1 / 100$ の污染水で飼育した群を正，正とし，通常水で飼育 した刘照群を $\mathbb{N}$ と名つけると，平均体值は次の如くで市 る(括弧内は観察匹数)。

$$
\begin{array}{llllll}
\text { I II } & \text { III } & \mathbb{N}
\end{array}
$$

生後14日目 $5.51(34) \quad 5.42(47) \quad 5.29(39) \quad 6.61(44)$ 生後35日目 17.65 ( 人) 15 , 우16) 19.12(令16, 우14) 19.97( ô 12, 우10) $19.44($ 승 27, 우 17)

このようにII，III群の生長は，対照と大差ないが，I 群には成長障害がみられた。

これらのマウスの一部を6 週以後に，同時同腹出生群 の間で交配すると, 出産しなかった早の割合はI：5/7, II $: 0 / 5, \mathbb{I I}: 0 / 6, \mathbb{N}: 0 / 3$ (数字は観察匹数)で, I 群のみには生殖能力の減少を認めた。

このような成績から，ある量以上の FP 摄取によっ て該世代は死をま放が机ても，生殖能力を失ならこと飞 よって種族保持が困難になるものであり，その量はかな り固定した值であることを示している。

239. 厇島県における原爆被爆者の未婚率について 渡边嶺男 (広島大原爆放射能医学研) 